Article

\title{
Resveratrol, EGCG and Vitamins Modulate Activated T Lymphocytes
}

\author{
Joseph Schwager*, Nicole Seifert, Albine Bompard, Daniel Raederstorff and Igor Bendik
}

check for updates

Citation: Schwager, J.; Seifert, N.; Bompard, A.; Raederstorff, D.; Bendik, I. Resveratrol, EGCG and Vitamins Modulate Activated T Lymphocytes. Molecules 2021, 26, 5600. https://doi.org/10.3390/ molecules 26185600

\section{Academic Editors:}

Thomas Netticadan, Jeffrey Wigle and Pema Raj

Received: 16 July 2021

Accepted: 8 September 2021

Published: 15 September 2021

Publisher's Note: MDPI stays neutral with regard to jurisdictional claims in published maps and institutional affiliations.

Copyright: (c) 2021 by the authors. Licensee MDPI, Basel, Switzerland. This article is an open access article distributed under the terms and conditions of the Creative Commons Attribution (CC BY) license (https:// creativecommons.org/licenses/by/ $4.0 /)$.
Department of Human Nutrition \& Health, DSM Nutritional Products Ltd., P.O. Box 2676, CH-4002 Basel, Switzerland; nicole.seifert@dsm.com (N.S.); albine.bompard@dsm.com (A.B.); raederstorf.daniel@orange.fr (D.R.); igor.bendik@dsm.com (I.B.)

* Correspondence: jpschwager@gmail.com; Tel.: +41-79-488-09-05

\begin{abstract}
Vitamins and bioactives, which are constituents of the food chain, modulate T lymphocyte proliferation and differentiation, antibody production, and prevent inflammation and autoimmunity. We investigated the effects of vitamins (vitamin A (VA), D (VD), E (VE)) and bioactives (i.e., resveratrol (Res), epigallocatechin-3-gallate (EGCG)) on the adaptive immune response, as well as their synergistic or antagonistic interactions. Freshly isolated T lymphocytes from healthy individuals were activated with anti-CD3/CD28 antibodies for 4-5 days in the presence of bioactives and were analyzed by cytofluorometry. Interleukins, cytokines, and chemokines were measured by multiple ELISA. Gene expression was measured by quantitative RT-PCR. Res and EGCG increased CD4 surface intensity. EGCG led to an increased proportion of $\mathrm{CD}^{+}$lymphocytes. Anti-CD3/CD28 activation induced exuberant secretion of interleukins and cytokines by T lymphocyte subsets. VD strongly enhanced $T_{h} 2$ cytokines (e.g., IL-5, IL-13), whereas Res and EGCG favored secretion of $\mathrm{T}_{\mathrm{h}} 1$ cytokines (e.g., IL-2, INF- $\gamma$ ). Res and VD mutually influenced cytokine production, but VD dominated the cytokine secretion pattern. The substances changed gene expression of interleukins and cytokines in a similar way as they did secretion. Collectively, VD strongly modulated cytokine and interleukin production and favored $T_{h} 2$ functions. Resveratrol and EGCG promoted the $T_{h} 1$ response. VA and VE had only a marginal effect, but they altered both $T_{h} 1$ and $T_{h} 2$ response. In vivo, bioactives might therefore interact with vitamins and support the outcome and extent of the adaptive immune response.
\end{abstract}

Keywords: resveratrol; EGCG; vitamin A; vitamin D; vitamin E; adaptive immune response; T lymphocytes; in vitro activation; cytokines; interleukins; synergism/antagonism

\section{Introduction}

The interactions between cell populations such as T and B lymphocytes orchestrate the highly complex pattern of the immune response to pathogens. T lymphocytes differentiate into two main distinct subsets of T effector cells, $\mathrm{T}$ helper type $1\left(\mathrm{~T}_{\mathrm{h}} 1\right)$ and $\mathrm{T}$ helper type 2 $\left(T_{h} 2\right)$ cells (reviewed in: [1]). $T_{h} 1$ cells secrete IL- 2 , IFN- $\gamma$, and TNF- $\alpha$ and are important for the development of delayed type hypersensitivity reactions and protective responses to intracellular pathogens [2]. $\mathrm{T}_{\mathrm{h}} 2$ lymphocytes express and secrete IL-4, IL-5, and/or IL-13 and are essential for the development of humoral and allergic reactions. The cytokine milieu of the local microenvironment is a major determinant of the direction of $T_{h}$ cell differentiation. Cytokines, including IL-12 and IFN- $\gamma$, directly induce progenitor (p) $T_{h}$ cell differentiation into $\mathrm{T}_{\mathrm{h}} 1$ cells, whereas IL-4 stimulates $\mathrm{pT}_{\mathrm{h}}$ cell differentiation into $\mathrm{T}_{\mathrm{h}} 2$ cells. Recent evidence also suggests an important role for cytokines such as IL-1 $\alpha$, IL- $1 \beta$, IL-15, and IL-18 in stimulating $\mathrm{T}_{\mathrm{h}} 1$ responses [2] and IL-10 and IL-13 in stimulating $\mathrm{T}_{\mathrm{h}} 2$ responses [3].

Vitamins and bioactives have long been known to modulate adaptive immune reactions [4,5]. Vitamin D (VD) and, in particular, the VD metabolite $1,25(\mathrm{OH})_{2} \mathrm{VD}_{3}$ has potent immune-regulatory effects and, thus, an important role in maintaining immune 
homeostasis. VD inhibits $C D 4^{+} \mathrm{T}_{\mathrm{h}} 1$ proliferation, the expression of IL-2 and INF- $\gamma$ and $\mathrm{CD}^{+} \mathrm{T}$ cell-mediated cytotoxicity. VD exerts a potent action on $\mathrm{T}_{\text {reg }}$ cells and their secreted cytokines and interleukins. VD mitigates the production of $T_{h} 1$ signature cytokines [6] and promotes the secretion of $\mathrm{T}_{\mathrm{h}} 2$ cytokines, but it also regulates the innate immune cells, since it stimulates human monocytes proliferation and differentiation [7]. Vitamin A (VA) and metabolically produced VA-retinoids are potent modifiers of rodent $\mathrm{T}_{\mathrm{h}} 1$ and $\mathrm{T}_{\mathrm{h}} 2$ responses [8,9]. Several mechanisms were proposed to account for these observations, including the direct downregulation of T cell IFN- $\gamma$ synthesis, direct promotion of $\mathrm{T}_{\mathrm{h}}$ 2-cell differentiation, and/or alteration of accessory or antigen presenting cell function toward a $\mathrm{T}_{\mathrm{h}}$ 2-inducing phenotype [10]. Vitamin $\mathrm{E}$ (or a-tocopherol) (VE) is a potent antioxidant vitamin that diminishes the release of pro-inflammatory cytokines and chemokines and modulates cellular immune function and cell adhesion. It reduces the production of reactive oxygen species (ROS), most likely via the NF-KB activation pathway [11-13]. Several studies have revealed that green tea extracts containing EGCG modulate T lymphocyte activity [14-18]. Similarly, Res shapes $\mathrm{CD} 4^{+}$and $\mathrm{CD} 8^{+}$lymphocyte activity and has dose-dependent stimulatory or inhibitory activities on the $\mathrm{T}$ lymphocyte immune response [19-27].

In this study, we evaluated the relative contribution of vitamins and bioactives to interleukin and cytokine production in activated human $\mathrm{T}$ lymphocytes, and we investigated their effects on activated human $\mathrm{T}$ lymphocyte function.

\section{Results}

\subsection{Phenotype of Activated PBMCs}

$\mathrm{T}$ lymphocytes and subpopulations thereof (i.e., $\mathrm{CD}^{+}, \mathrm{CD}^{+}$, and $\mathrm{CD}^{+} \mathrm{T}$ lymphocytes) were isolated from PBMCs by negative selection and then analyzed by cytofluorometric analysis. Isolated PBMCs contained $27 \% \pm 3 \% \mathrm{CD}^{8+}$ and $59 \% \pm 2 \% \mathrm{CD}^{+}$lymphocytes $(n=3)$. Selected $\mathrm{CD}^{+}$lymphocytes were $\mathrm{T}$ lymphocytes, since about $60 \%$ and $35 \%$ of these cells were $\mathrm{CD} 4^{+}$and $\mathrm{CD} 8^{+}$, respectively. $\mathrm{CD}^{+}$cells were $\mathrm{CD} 23^{+} / \mathrm{CD} 18^{-}, \mathrm{CD}^{-} 6^{-}$, $\mathrm{CD} 11 \mathrm{c}^{-}$, and $\mathrm{CD} 14^{-}$, which reflects the absence of $\mathrm{B}$ cells and monocytes/macrophages. Furthermore, $\sim 40 \%$ of $\mathrm{CD}^{+}$cells expressed the $\alpha \beta$ TCR (results not shown). Negatively selected $\mathrm{CD}^{+}{ }^{+}$or $\mathrm{CD} 8^{+}$lymphocytes were $>95 \% \mathrm{CD}^{+}$and $\sim 80-90 \% \mathrm{CD}^{+}$, respectively (Supplementary Material Figure S1). $\mathrm{CD} 4^{+}$lymphocytes were $\mathrm{CD} 18^{+}$and $\mathrm{CD} 40^{-}$, which indicated the absence of $\mathrm{B}$ lymphocytes. A substantial proportion of freshly isolated $\mathrm{CD}^{+}$lymphocytes expressed CCR4 (not shown); $\mathrm{CD} 8^{+}$selected lymphocytes were $\mathrm{CD} 18^{+}$ and $\mathrm{CD}^{-}$.

\subsection{In Vitro Differentiation of Activated T Lymphocytes}

Blood cells were cultured with anti-CD3/CD28 (immobilized on Dynabeads ${ }^{\mathrm{TM}}$ ) to induce T lymphocyte proliferation and differentiation, see [28]. Cytofluorometric analysis was performed after 5 days of culture. The proportion of $\mathrm{CD} 4^{+}$and $\mathrm{CD} 8^{+}$lymphocytes was similar in both unstimulated and activated cells. Anti-CD3/CD28 stimulation induced the expansion of the CCR4 ${ }^{+}$cell population (Figure 1). The activated cells were TCR $\alpha \beta^{+}$, but they did not express TCR $\gamma \delta$ and TLR4 determinants (not shown). The data indicated that the entire $\mathrm{CD}^{+}$lymphocyte population expanded after anti-CD3/CD28 activation. We also prepared $\mathrm{CD}^{+}$and $\mathrm{CD} 8^{+}$lymphocytes and found that both cell populations vigorously proliferated when stimulated with anti-CD3/CD28. Both T lymphocyte subsets conserved their respective phenotypes during the entire culture period. Anti-CD3/CD28 stimulated cells expressed increased cell surface density of CD4 and CD8 determinants (compared to non-activated cells). 

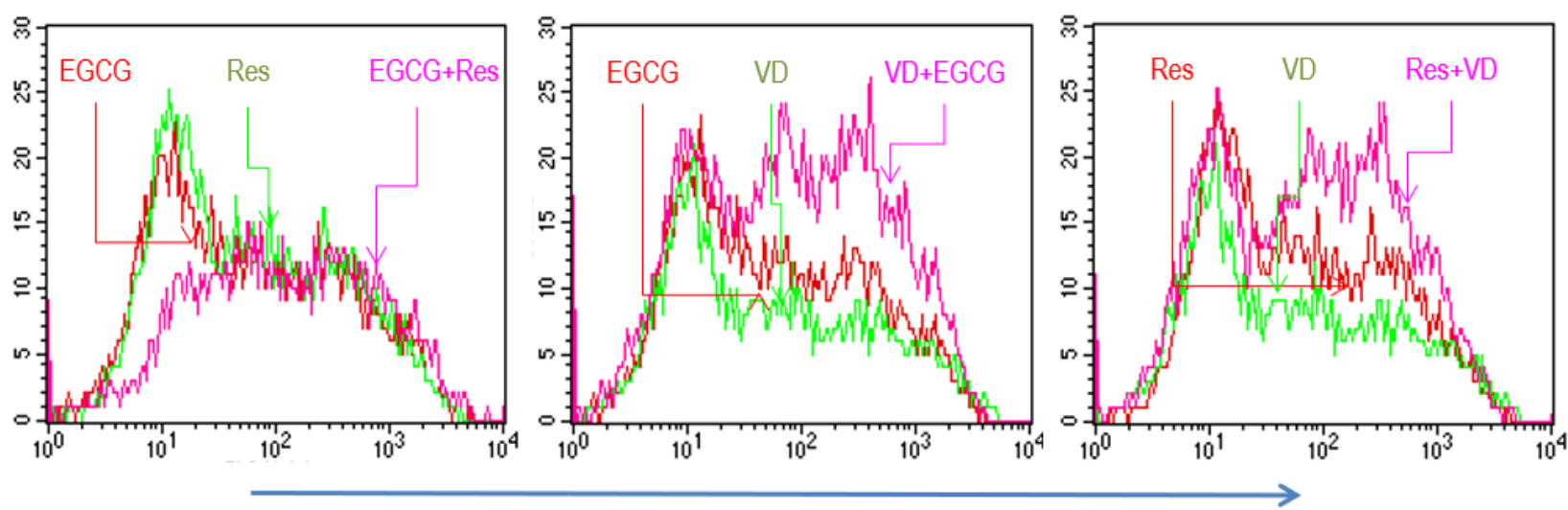

CCR4

(a)
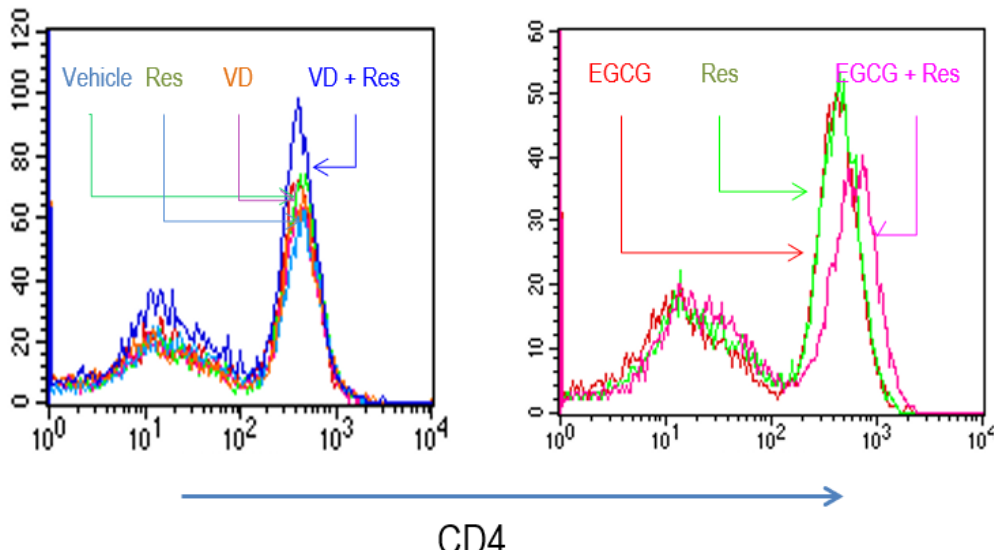

(b)
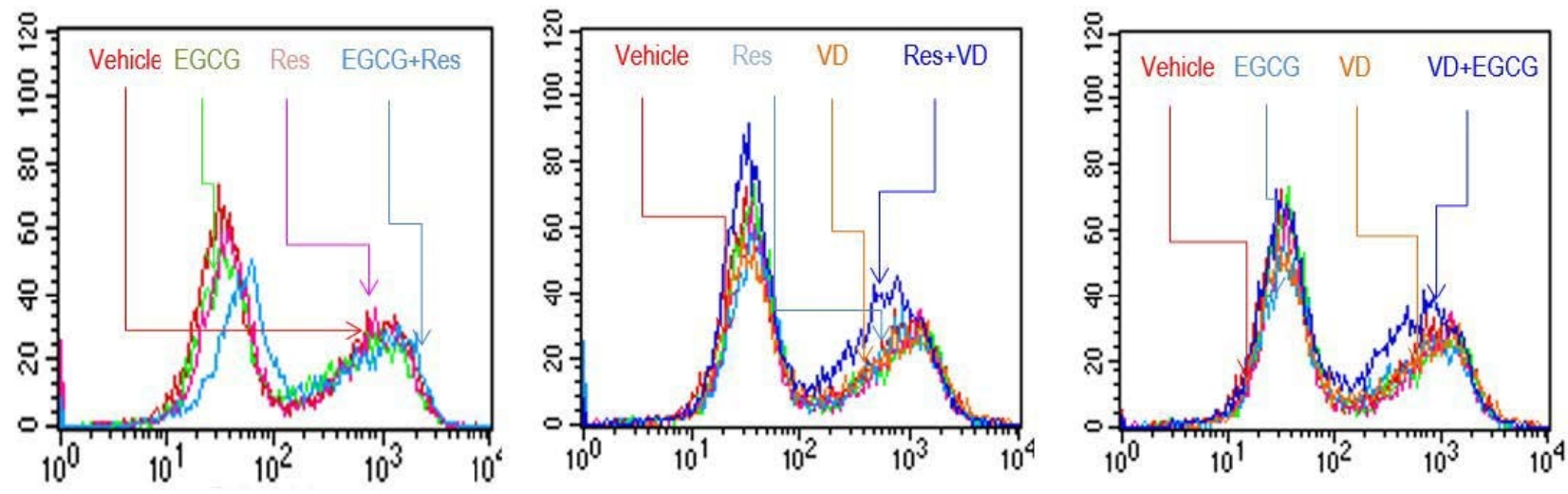

CD8

(c)

Figure 1. Influence of substances on lymphocyte surface determinants. Anti-CD3/CD28 activated PBMCs were cultured for 5 days, see [20], in the presence of indicated substances and the cytofluorometric profiles were determined. Where not indicated, similar staining pattern was observed in the absence of substances as with EGCG or Res. Cytofluorometric profiles were obtained by incubating cells with anti-CCR4 (a), anti-CD4 (b) and anti-CD8 (c). 


\subsection{Effects of Res, EGCG, and Vitamins on the Phenotype of In Vitro Activated T Cells}

We investigated whether anti-CD3/CD28 activated T lymphocytes had an altered phenotype when they were cultured in the presence of substances. Res or EGCG did not markedly alter CD4 surface expression, but it increased expression when both substances were combined (Figure 1 and Figure S2). VD had an opposing effect and reduced mean surface intensity of $\mathrm{CD} 4$ on activated T lymphocytes. VA and VE had no significant effects on CD4 or CD8 surface intensity or percentage of positive cells (results not shown). EGCG slightly shifted the CD4/CD8 ratio to an increased proportion of $\mathrm{CD} 8^{+}$cells (Figure S2). In contrast, Res, VA, VD, and VE had no impact on the CD4/CD8 ratio in stimulated $\mathrm{T}$ cells (Figure S2). The combination of VD with Res or EGCG further altered CD8 surface expression; Res and EGCG, alone or combined, favored a high level of CCR4 expression, a marker for $\mathrm{T}_{\mathrm{h}} 1$ lymphocytes. Conversely, VD reduced its surface density (Figure 1).

\subsection{Cytokines Produced by In Vitro Activated T Lymphocytes}

Activated T lymphocytes differentiated into $\mathrm{CD} 4^{+} \mathrm{T}_{\mathrm{h}}$ cell subsets, each of which produced a genuine set of $\mathrm{T}_{\mathrm{h}}$ lineage signature cytokines and chemokines [2]. Similarly, CD8 ${ }^{+}$ lymphocytes preferably secreted cytokines, which are instrumental for cellular immune functions. We investigated the changes of secreted cytokines by activated $\mathrm{T}$ lymphocytes and $\mathrm{CD}^{+}$or $\mathrm{CD}^{+}$lymphocyte subsets. Anti-CD3/CD28 activation induced exuberant secretion of interleukins and cytokines, which mirror the in vitro differentiation of $T_{h}$ lymphocyte subsets. INF- $\gamma$ and IL- 2 were prototypic for the $T_{h} 1$ compartment, whereas IL-5 and IL-13 were distinctive for activated $\mathrm{T}_{\mathrm{h}} 2$ lymphocytes (Supplementary Materials Table S1). Activated T lymphocytes also produced large amounts of chemokines, including CCL5/RANTES, CXCL8/IL-8, MIP-1a/CCL3, and MIP-1ß/CCL4 (Supplementary Materials Table S1). Similarly, isolated $\mathrm{CD}^{+}$or $\mathrm{CD}^{+}$lymphocytes secreted substantial amounts of cytokines upon activation with anti-CD3/CD28. Compared to CD8 $8^{+}$lymphocytes, activated $\mathrm{CD} 4^{+}$cells produced significantly more IL-2, IL-6, IL-9, IL-10, and IL-17, and TNF- $\alpha$ cells produce ${ }^{+}$lymphocytes out-performed CD4 ${ }^{+}$cells in the production of IL-5, IL-13, and various chemokines (Supplementary Materials Table S1).

\subsection{Selective Effects of Vitamins and Polyphenols on Cytokines and Interleukins Produced by Activated T Lymphocytes}

The presence of substances during lymphocyte activation and differentiation influenced interleukin and cytokine production. Res significantly increased the production of IL-2 (Figure 2A). It also augmented the production of IL-6, whereas it blunted chemokine CXC/CL8 production (Figure 2D,K). VD drastically enhanced IL-13 secretion of activated T lymphocytes and significantly augmented IL-5 and IL-6 production (Figure 2E,G,K). $\mathrm{VD}$, however, was less active than its physiological metabolite $1,25(\mathrm{OH})_{2} \mathrm{D}_{3}$ (Supplementary Materials Table S2). VA promoted the production of IL-2 and IL-5 (Figure 2A,E,I). Retinoic acid (used at 0.01-1 nM) had similar effects on IL-2 (Supplementary Materials Table S2). VE altered cytokines and chemokines produced by activated $\mathrm{T}$ lymphocytes at high concentration (i.e., $25 \mu \mathrm{M}$ ). Since changes induced by one substance might be counterbalanced or enforced by concomitant changes of another substance, we determined how the substances influenced the ratio of secreted cytokines and, therefore, the $T_{h} 1 / T_{h} 2$ balance. Resveratrol significantly increased the IL-2/IL-13 ratio, which is characteristic of an increased $T_{h} 1$ response (Table 1 ). Regarding $T_{h} 1$ cytokines, Res had a higher impact on IL-2 compared to INF- $\gamma$. Similarly, Res also increased IL-2 production relative to chemokines (CCL5/RANTES, CXCL10/IP-10) and IL-6 (Table 1). EGCG and Res had many similar effects on chemokines. VA and VE had only minor effects on these ratios. VD induced drastic changes in the ratio of prototype $T_{h} 1$ and $T_{h} 2$ interleukins since it significantly up regulated the $T_{h} 2$ at the expense of decreased $T_{h} 1$ interleukin production (Table 2). This is also reflected in the ratio for cumulative prototype $T_{h} 1$ and $T_{h} 2$ cytokines, which were defined as IL-2, IFN- $\gamma$ and IL-5, IL-13, respectively. 
A

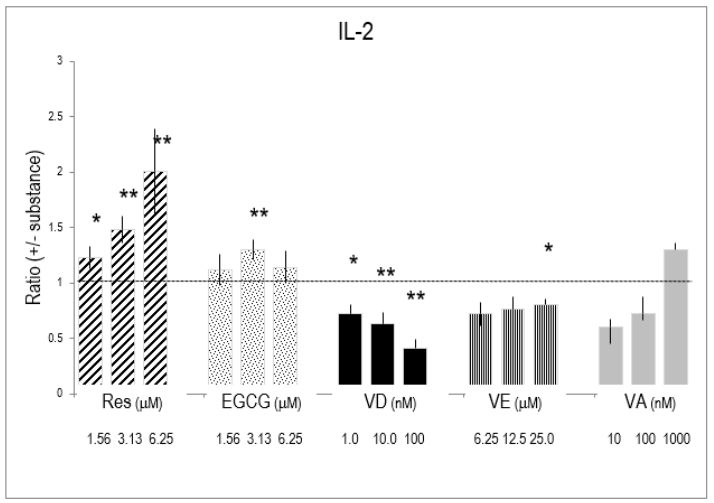

C

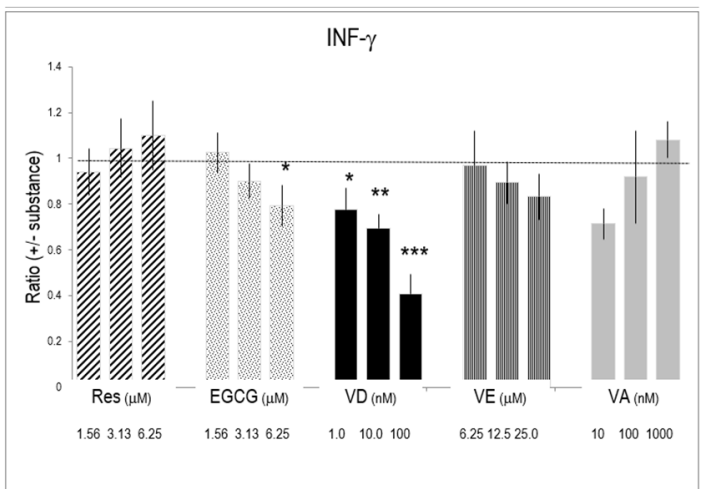

E

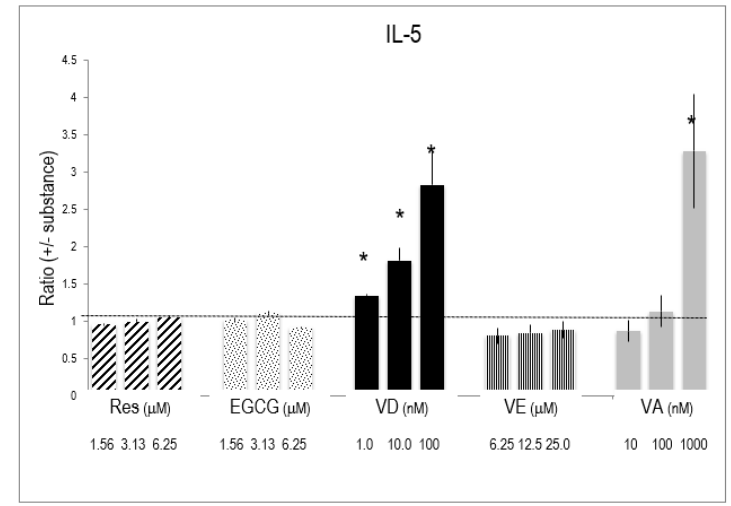

G

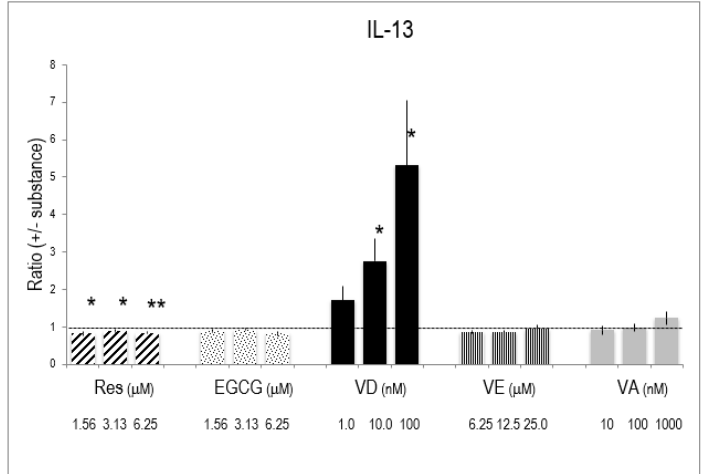

B

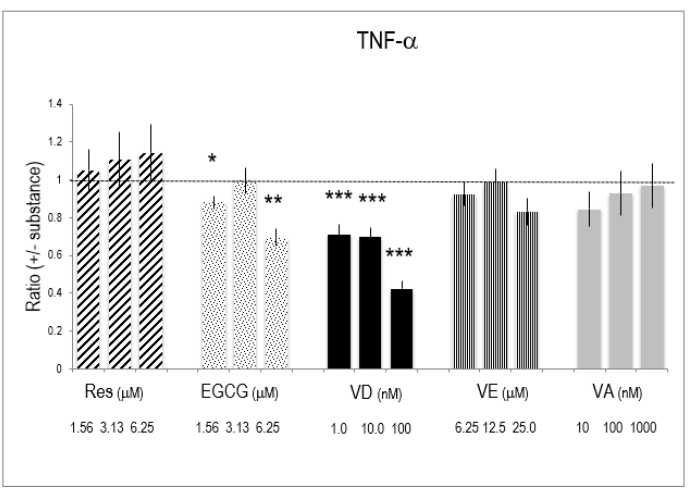

D

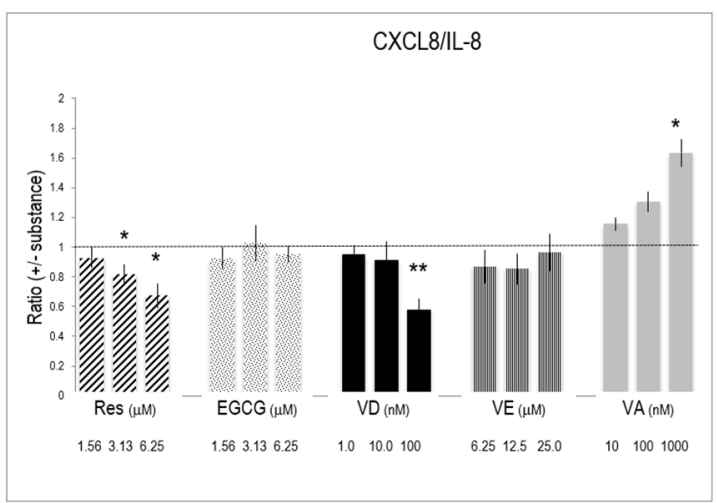

F

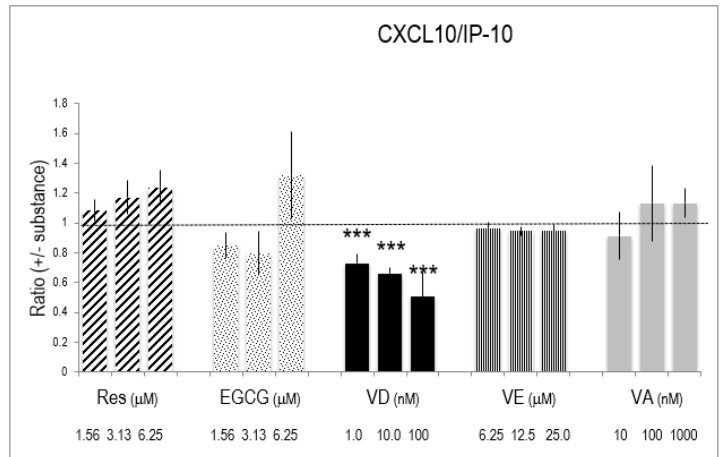

$\mathrm{H}$

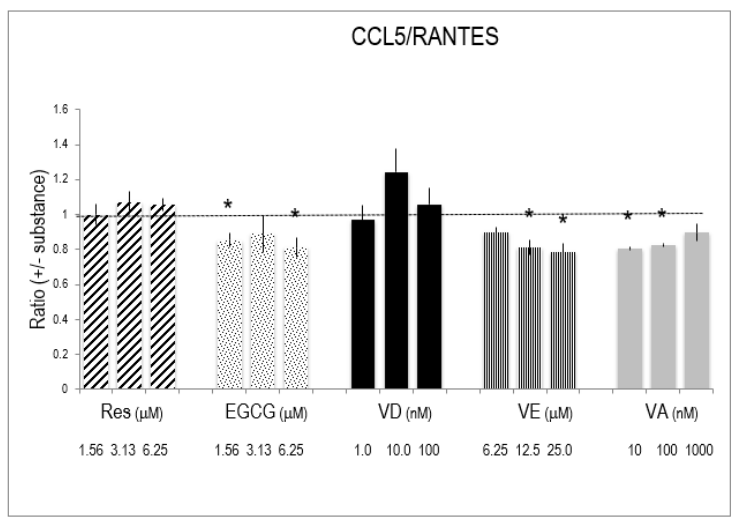

Figure 2. Cont. 

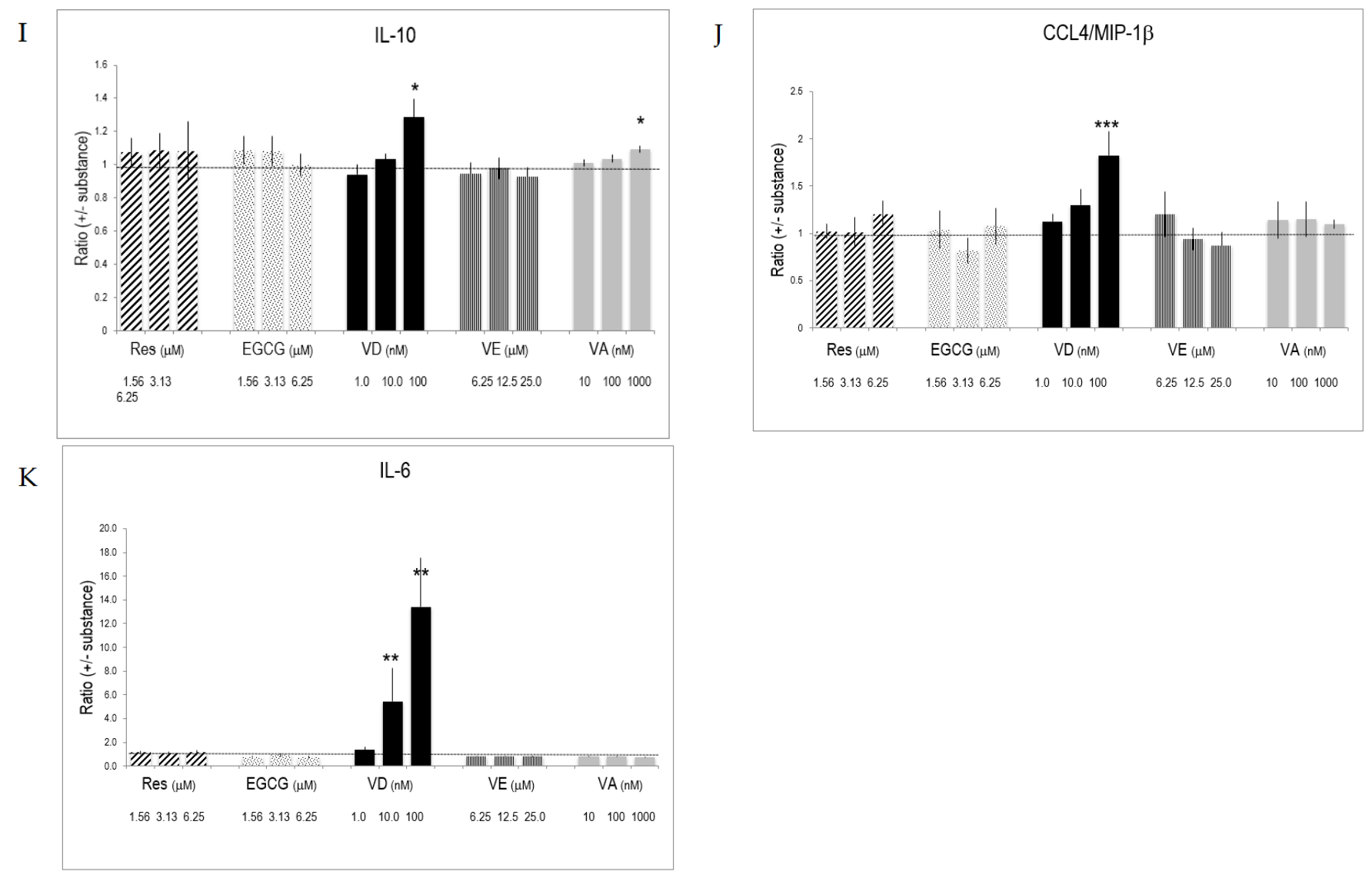

Figure 2. Cytokines and interleukins produced by activated T lymphocytes and the impact of substances on their production. $\mathrm{CD}^{+}$cells were stimulated for 5 days with anti-CD3/CD28 in the presence of various concentrations of substances. Cytokines, interleukins, and chemokines secreted by triplicate cultures were determined by multiplex ELISA. The data were normalized against values obtained from vehicle-treated cultures. Bars indicate $\mathrm{SD}(n=3) .{ }^{*}=p<0.05 ;{ }^{* *}=p<0.01$; ${ }^{* * *}=p<0.001$. (A-K) refers to measured secretion of IL-2, TNF- $\alpha$, INF- $\gamma$, CXCL8/IL-8, IL-5, CXCL10/IP-10, IL-13, CCL5/RANTES, IL-10, CCL4/MIP-1 and IL-6, respectively. The dotted line in the graphs indicates the level of the reference ratio $(=1)$.

Table 1. Effect of substances on the $T_{h} 1 / T_{h} 2$ ratio.

\begin{tabular}{|c|c|c|c|c|c|c|c|}
\hline & $\begin{array}{c}\text { Cumulative } \\
\text { Prototype } \\
\mathrm{T}_{\mathrm{h}} 1 / \mathrm{T}_{\mathrm{h}} 2^{(1)}\end{array}$ & IL-2/IL-13 & IL-2/INF- $\gamma$ & INF-/IL-5 & IL-2/TNF- $\gamma$ & IL-2/CCL5 & IL-2/IL-6 \\
\hline$+\operatorname{Res}$ & $1.39 \pm 0.19^{(2)}$ & $2.45 \pm 0.19$ & $1.47 \pm 0.25$ & $2.08 \pm 0.61$ & $2.10 \pm 0.21$ & $1.78 \pm 0.21$ & $2.41 \pm 0.21$ \\
\hline$+\mathrm{EGCG}$ & $1.52 \pm 0.24$ & $1.37 \pm 0.24$ & $0.78 \pm 0.39$ & $2.52 \pm 0.82$ & $1.74 \pm 0.07$ & $1.19 \pm 0.41$ & $1.62 \pm 0.07$ \\
\hline$+\mathrm{VD}$ & $0.15 \pm 0.08$ & $0.13 \pm 0.08$ & $6.31 \pm 4.85$ & $0.20 \pm 0.08$ & $0.90 \pm 0.61$ & $0.94 \pm 0.53$ & $1.09 \pm 0.61$ \\
\hline$+\mathrm{VA}$ & $1.15 \pm 0.15$ & $1.40 \pm 0.15$ & $1.99 \pm 0.47$ & $0.85 \pm 0.20$ & $2.91 \pm 0.21$ & $1.95 \pm 0.34$ & $2.86 \pm 0.21$ \\
\hline$+\mathrm{VE}$ & $0.42 \pm 0.02$ & $0.52 \pm 0.02$ & $1.45 \pm 0.18$ & $0.32 \pm 0.10$ & $0.73 \pm 0.14$ & $1.22 \pm 0.03$ & nd ${ }^{(3)}$ \\
\hline
\end{tabular}

Secreted interleukins and cytokines of PBMCs, which were activated with anti-CD3/CD28 and cultured for 5 days in the presence or absence of indicated substances, were measured (in triplicates). Data were normalized against 'activated cells' (which were set as 1). Mean values \pm SEM are given $(n=4) .{ }^{(1)}$ (prototype $\mathrm{T}_{\mathrm{h}} 1: \mathrm{IL}-2$, INF- $\gamma$ )/prototype $\mathrm{T}_{\mathrm{h}} 2$ : IL-5, IL-13). ${ }^{(2)}$ ratio of secreted interleukin or cytokine $=\frac{(\text { Activated cells }+ \text { substance })}{\text { Activated cells only }}{ }^{(3)}$ not done.

Both $\mathrm{CD}^{+}$and $\mathrm{CD}^{+}$lymphocytes responded to anti-CD3/CD28 stimulation. Yet, the extent of activation was different, since activated $\mathrm{CD} 4^{+}$lymphocytes secreted higher amounts of cytokines and interleukins than CD8 ${ }^{+}$lymphocytes did (Supplementary Materials Table S1). Vitamins and polyphenols had similar effects on activated CD4 ${ }^{+}$and $\mathrm{CD}^{+}$lymphocyte subsets (Figure S1). 
Table 2. Substances induced shift in the $\mathrm{T}_{\mathrm{h}} 1$ and $\mathrm{T}_{\mathrm{h}} 2$ prototype interleukin secretion.

\begin{tabular}{|c|c|c|c|c|}
\hline \multirow{2}{*}{$\begin{array}{c}\text { Cells Stimulated in the } \\
\text { Presence of } \\
\text { no substance }\end{array}$} & \multicolumn{2}{|c|}{ Ratio IL-2/IL-13 ( \pm SEM) ${ }^{(1)}$} & \multicolumn{2}{|c|}{ Ratio Cumulative $T_{h} 1 / T_{h} 2( \pm S E M){ }^{(2)}$} \\
\hline & 1 (ref) & & 1 (ref) & \\
\hline Res & $2.45 \pm 0.19$ & $*$ & $1.39 \pm 0.19$ & * \\
\hline EGCG & $1.37 \pm 0.24$ & & $1.52 \pm 0.24$ & * \\
\hline VD & $0.13 \pm 0.08$ & * & $0.15 \pm 0.08$ & * \\
\hline VA & $1.40 \pm 0.15$ & & $1.15 \pm 0.15$ & \\
\hline VE & $0.52 \pm 0.02$ & & $0.42 \pm 0.02$ & \\
\hline
\end{tabular}

PBMCs were activated with anti-CD3/CD28 and cultured for 5 days. Interleukins were quantified in culture supernatants, normalized (against 'no substance'), and the ratio was calculated as indicated. ${ }^{(1)}$ Ratio of secreted interleukins $=$ activated cells + substance $/$ activated cells only. ${ }^{(2)}$ Th1: IL-2 (+) IFN $\gamma$; Th2: Il-5 (+) IL-13. ${ }^{*} p<0.05$ (vs. ref).

\subsection{Interactions between Vitamins and Polyphenols on Cytokine Production by Activated T Lymphocytes}

Res and VD had the strongest, and often opposed, effects on cytokine secretion. We investigated whether one of these bioactives had a predominant influence. To this aim, the effect of combinations of Res and VD was evaluated on the secretion pattern of activated $\mathrm{T}$ lymphocytes. $\mathrm{T}_{\mathrm{h}} 1$-specific cytokine production was dominated by VD rather than by Res (Figure 3). For instance, VD reduced the enhancing effects of Res on IL-2 production to VD-specific levels. Alternatively, INF- $\gamma$ production was similar for VD-only conditions and in combinations of VD and Res. This reflects a prevailing effect of VD. The level of $\mathrm{T}_{\mathrm{h}}$ 2-specific IL-13 was dominated by VD. We observed synergistic effects between Res and VD on IL-13 production, since it exceeded the sum of single effects of Res and VD (Figure 3). Regarding TNF- $\alpha$ or CXCL8/IL-8, the combinations of the two substances generated an intermediate pattern of cytokine production. Other combinations of substances (e.g., VD with VE, VD with VA, VD with EGCG) corroborated the dominant effect of VD over other vitamins and bioactives (data not shown).
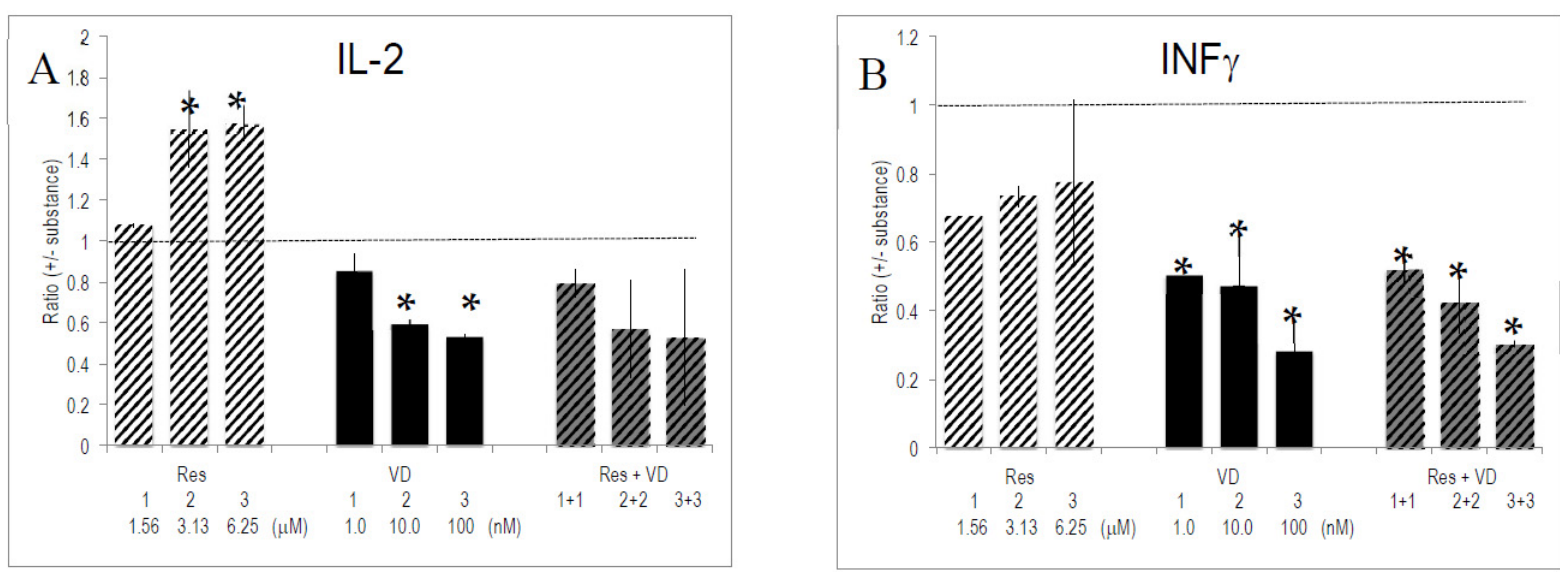

Figure 3. Cont. 

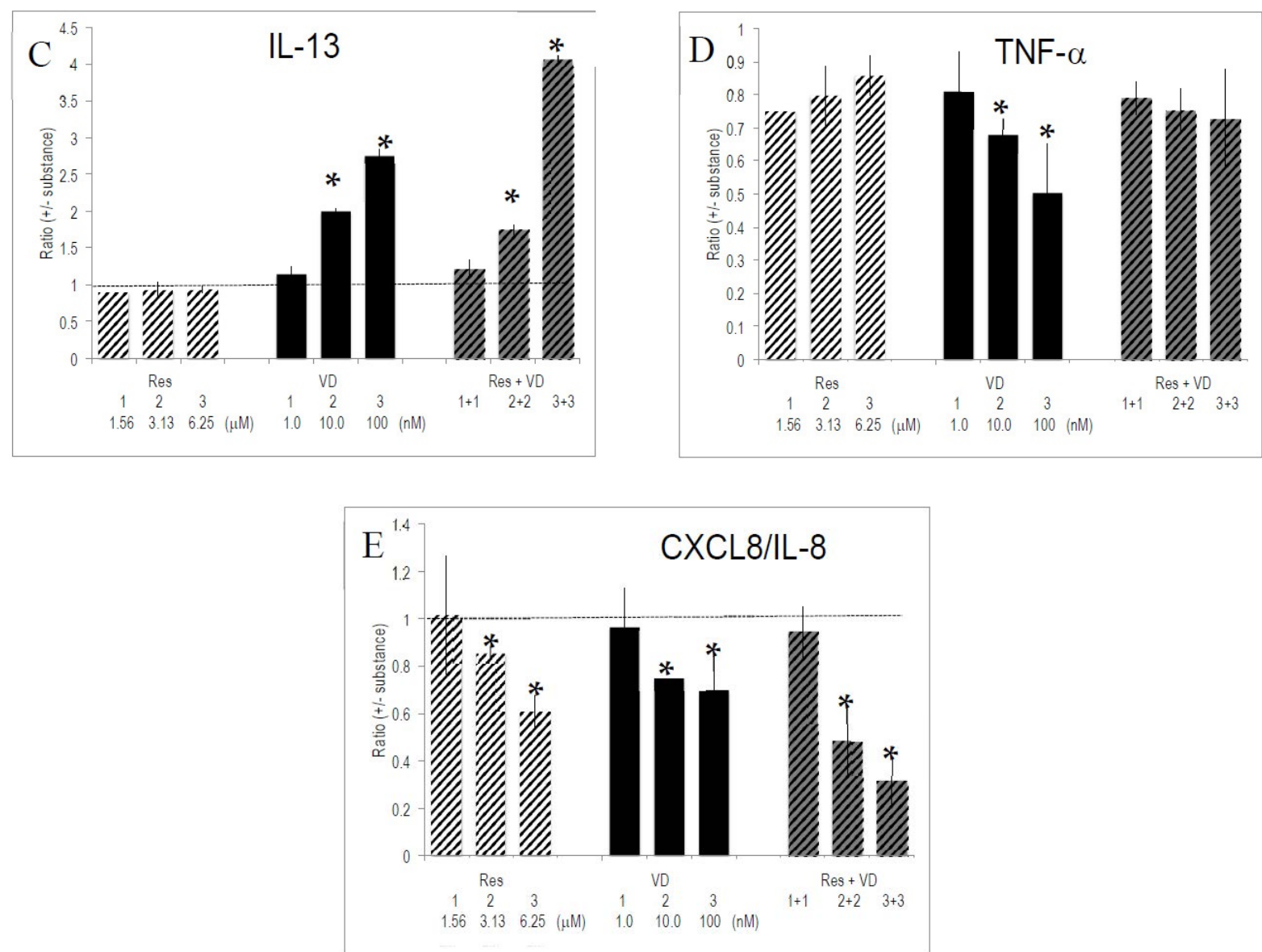

Figure 3. Effect of combinations of substances on cytokine/interleukin production. Anti-CD3/CD28 activated PBMCs were cultured for 4 days (see: reference added in proof) with the indicated substances and combinations thereof. Gene expression was quantified by PCR and the ratio of expression (+/ - substances) was computed as described in Materials and Methods. Bars indicate SEM ( $n=4$ experiments with donors of PBMCs, each done in triplicate cultures). ${ }^{*}$ indicate $p$ values $<0.05$ versus anti-CD3/CD28 stimulated PBMCs. (A-E) refers to the ratio of secreted IL-2, INF- $\gamma$, IL-13, TNF- $\alpha$ and CXCL8/IL-8, respectively.

\subsection{Effects of Vitamins and Polyphenols on Gene Expression of Activated T Lymphocytes}

Some of the tested substances considerably influenced cytokine gene expression (Figure 4). The most prominent effects were observed with VD, since it blunted expression levels of IL-2, INF- $\gamma$, but also IL-17, IL-21, and TNF- $\alpha$. In contrast, it significantly increased gene expression of $\mathrm{T}_{\mathrm{h}} 2$ prototype interleukins, such as of IL-5 and IL-13, whereas IL-10 expression was moderately changed. IL-6, which promotes $T_{h} 2$ and $B$ cell differentiation [29], was strongly enhanced by VD. Res, EGCG, VE, and VA had weak effects on cytokine gene expression. However, Res and EGCG increased $\mathrm{T}_{\mathrm{h}} 1$ specific IL-2 and INF- $\gamma$. 

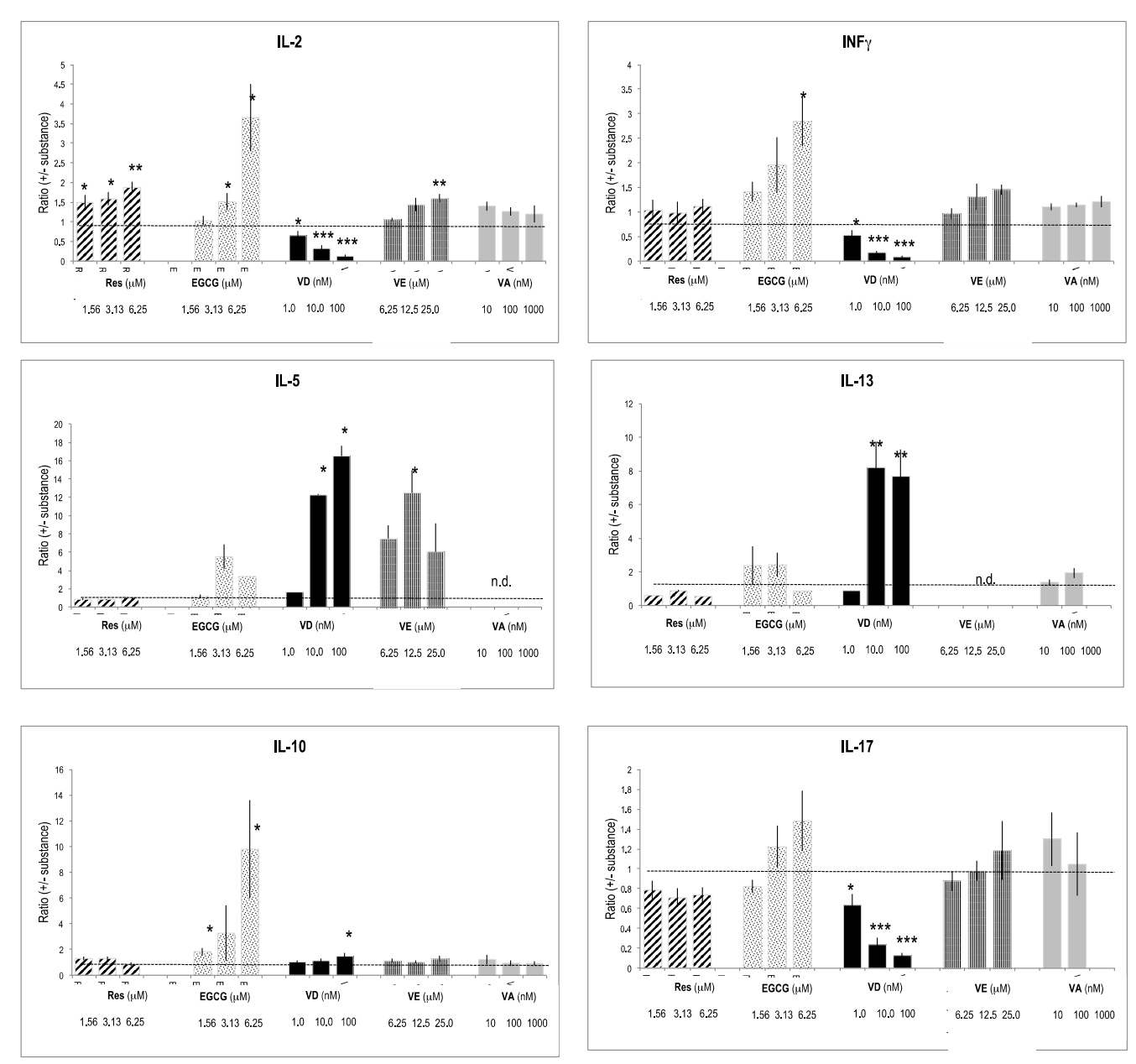
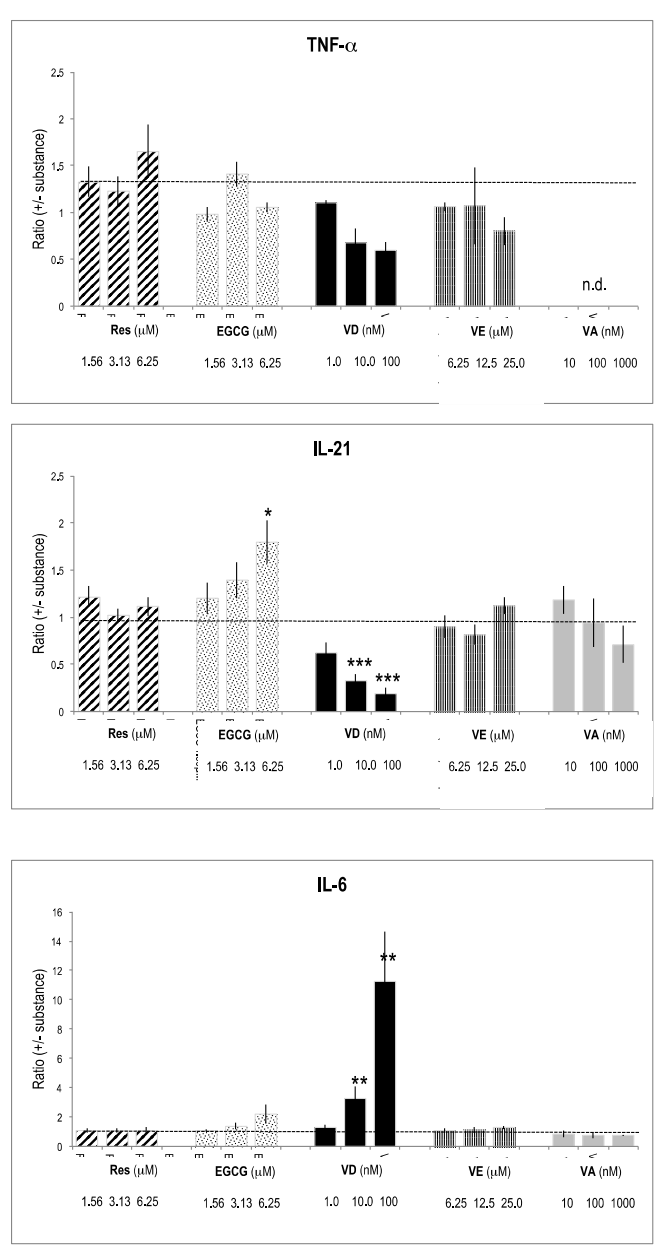

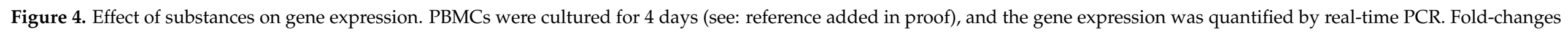

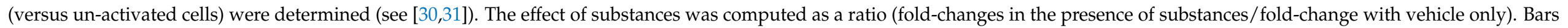
indicate $\mathrm{SD}(n=4) .{ }^{*}=p<0.05 ;^{* *}=p<0.01 ;{ }^{* * *}=p<0.001$. The dotted line in the graphs indicates the level of the reference ratio $(=1)$. 


\section{Discussion}

This study shows that bioactives and vitamins modulate the composition of $\mathrm{T}$ lymphocyte subsets and significantly influence the secretion of interleukins and cytokines. Activation of peripheral blood leukocytes, or subsets thereof, with anti-CD3/CD28 induced the expansion of $\mathrm{T}$ lymphocytes. The presence of EGCG slightly favored the proliferation of $\mathrm{CD}^{+}$lymphocytes. The impact of $\mathrm{VA}, \mathrm{VD}, \mathrm{VE}$, and Res on the $\mathrm{CD} 4^{+} / \mathrm{CD} 8^{+}$ratio was minor. Yet, the combination of VD and EGCG, or Res modulated surface density of CD4 and CD8 determinants and it promoted the expression of CCR4. This receptor is a marker of $\mathrm{T}_{\mathrm{h}} 2$ subsets; thus, the observed phenotypic changes are consistent with an increased $\mathrm{T}_{h} 2$ response, which might be mainly orchestrated by VD [32]. These changes suggest that bioactives and vitamins, as well as combinations thereof, alter the Tlymphocyte compartment. They may influence the overall CD4/CD8 balance as well as the differentiation of T lymphocyte subsets. It should be noted, that among vitamins, VD rather than VA and VE showed these effects on $\mathrm{T}$ lymphocyte compartments.

The underlying cellular mechanisms that trigger these changes are numerous and presumably dependent on the cell types involved. Res and EGCG impaired the production of reactive oxidant species (ROS) (reviewed by [33,34]); VE also influenced ROS production $[35,36]$. As a consequence, cytokines and inflammatory interleukins like TNF- $\alpha$ and IL- $1 \alpha / \beta$ are mitigated by the presence of Res or EGCG $[30,37,38]$ in a cell- and tissuedependent manner [39]. It should be noted that Res up regulated IL-6 in most of these compartments [39]. Conversely, Res reduced T cell activation in murine spleen cells [40]. The generation of ROS may be implicated in the favorable growth of $\mathrm{T}_{\text {reg }}$ cells in the presence of resveratrol [41]. As described previously [38,42] Res differently modulated macrophages, spleen cells, and peripheral blood leukocytes. In line with this observation, Res had pleiotropic effects on gene and protein expression and reduced pro-inflammatory cytokine release from T-lymphocytes [21], and it altered nuclear factors essential to the process of lymphocyte differentiation [43].

EGCG was also shown to influence cell growth in lymphoid cells and eventually the immune system ([31,44], reviewed in [45]). We observed only minor effects of VA and its physiological correlate RA on the adaptive immune response. As shown in previous studies, RA activated effector $\mathrm{CD} 4^{+} \mathrm{T}$ lymphocytes via the production of IFN- $\gamma$ by lymphocytes of the innate lymphoid cells [46]. It also influenced $\mathrm{T}_{\mathrm{h}} 2$ responses in human CD4 ${ }^{+}$ Tlymphocytes in vitro and in vivo $[9,41,47]$.

VE, which has anti-inflammatory and antioxidant properties [35], showed favorable effects on T lymphocytes during immunosenescence; in vivo studies revealed that dietary supplementation with VE improved the immune response of $\mathrm{T}$ lymphocytes in aged animals or individuals [11-13]. It also influences immune function through modulating cAMP levels, and ultimately $\mathrm{PGE}_{2}$ [36]. The moderate effect of VE in this study might be due to a relatively poor cellular 'loading' during in vitro $\mathrm{T}$ lymphocyte activation.

As shown in numerous seminal studies, VD has a variety of effects on the adaptive immune response [48-56], as well as on the innate immune response. Historically, VD was first associated with immunosuppression, while more recent evidence demonstrated its impact on $\mathrm{T}$ regulatory $\left(\mathrm{T}_{\text {reg }}\right)$ lymphocytes. There is a possible pathway for crosstalk between VD and Res at the VDR signaling [57]. Interactions between Res and VD have also been elucidated in the innate immune response [58].

In this study we have evidenced the interactions between bioactives and vitamins. While the effect on the $T_{h} 1 / T_{h} 2$ response revealed some antagonism between Res and VD, we also observed synergistic interactions between the two substances, e.g., in the expression of IL-13; other interactions were additive (Figure 3). This is in line with published data, which showed interactions between bioactives and/or vitamins [44,59-62].

The present study indicates that Res and VD modulate the activity of $T_{h} 1$ and $T_{h} 2$ subsets, respectively. The two substances act on distinct and complementary arms of the immune response, since Res increased $T_{h} 1$ immunity, while $V D$ favored $T_{h} 2$ responses. The 
two substances profoundly differ in their bioavailability and plasma kinetics. Res, as well as EGCG, are metabolized within hours after dietary intake [63-65], whereas VD levels remain high for prolonged periods after uptake [66]. Cellular levels of Res and EGCG might exceed plasma levels (see also [67]). We anticipate that these distinct kinetics offer an approach for targeting the effects of polyphenols versus those of VD on the immune response; due to very short half-life in plasma, Res or EGCG can only briefly influence the immune response, while VD has long-lasting effects. Res and VD react with different cell-based molecules or receptors, which might enable dichotomic cellular effects. The biological consequence of opposite effects of Res and VD, as well as their specific temporal pattern, might result in fine-tuning the adaptive immune response. This needs to be corroborated in future studies.

\section{Methods}

\subsection{Reagents}

Ethanol and DMSO were from Sigma (Sigma-Aldrich, Buchs, Switzerland). Vitamin A (VA), vitamin $\mathrm{E}$ (i.e., all-rac $\alpha$-tocopherol) (VE), retinoic acid (RA), $1,25(\mathrm{OH})$ vitamin $\mathrm{D}_{3}$, and epigallocatechin 3-gallate (EGCG) were from Sigma (Sigma-Aldrich, Buchs, Switzerland); $25(\mathrm{OH})$ vitamin $\mathrm{D}_{3}(\mathrm{VD})$ was from DSM Nutritional Products (Kaiseraugst, Switzerland); trans-resveratrol (Res) was from Sigma (Sigma-Aldrich, Buchs, Switzerland) or from DSM Nutritional Products (Kaiseraugst, Switzerland). All substances were $>99 \%$ pure. Compounds were dissolved in ethanol (VA, RA, VD, VE) or in DMSO (Res, EGCG) and added to the culture medium concomitantly with the stimulus. Final ethanol and DMSO concentration were $0.05 \%$ and $0.5 \%$, respectively.

Lymphoprep ${ }^{\circledR}$ was from Axis Shield AS (Oslo, Norway). Depletion Dynabeads ${ }^{\circledR}$ for isolating human $\mathrm{T}$ cells, $\mathrm{CD} 4^{+}$, or $\mathrm{CD} 8^{+}$lymphocytes by negative selection were from Life Technologies Europe B.V (Zug, Switzerland). Human recombinant interferon- $\gamma$ (IFN- $\gamma$ ) was from Preprotech EC (London, UK). Primers and probes used in RT-PCR were designed with the Primer Express ${ }^{\mathrm{TM}}$ program (Applied Biosystems Inc., Foster City, CA, USA) and synthesized by Sigma (Sigma-Aldrich, Buchs, Switzerland). Dynabead immobilized antiCD3/anti-CD28 (i-antiCD3/CD28) were from Invitrogen (Life Technologies Europe B.V. Zug, Switzerland).

Fluorochrome-conjugated monoclonal antibodies were purchased from BD Pharmingen (San Diego, CA, USA) or eBioscience (Vienna, Austria) and used according to the manufacturers' indications. Monoclonal antibodies against CD4, CD11c, CD23, CD86, CCR3, CCR6, TCR $\alpha / \beta$, and TLR2 were conjugated with FITC; monoclonal antibodies against CD8, CD14, CD18, CCR4, CCR5, TCR $\gamma / \delta$, and TLR4 were conjugated with PE.

\subsection{Peripheral Blood Leukocytes and Isolation of Human T Lymphocytes}

Buffy coats were prepared from blood obtained from healthy humans at the Blood Donor Center University Hospital (Basel, Switzerland). Peripheral blood mononuclear cells (PBMCs) were isolated by Lymphoprep ${ }^{\circledR}$ within $<3 \mathrm{~h}$ after blood withdrawal and used for experiments immediately. T lymphocytes were further isolated from PBMCs using the Dynabeads ${ }^{\mathrm{TM}}$ Untouched $^{\mathrm{TM}}$ Human T cells kits. T lymphocytes, CD4 ${ }^{+}$, and CD8 ${ }^{+}$lymphocytes were isolated by negative selection using Depletion Dynabeads ${ }^{\circledR}$ Untouched $^{\mathrm{TM}}$ Human T cells, Untouched ${ }^{\mathrm{TM}}$ Human CD4 T cells, and Untouched ${ }^{\mathrm{TM}}$ Human CD8 T cells (Life Technologies Europe B.V., Zug, Switzerland), respectively, following the experimental protocols provided by the manufacturer. In some cases, isolated PBMC were cryopreserved in fetal bovine serum (FBS) containing 10\% DMSO (both from Sigma-Aldrich, Buchs, Switzerland) and stored in liquid nitrogen before being used for experiments.

\subsection{Activation of T Lymphocytes with Immobilized Anti-CD3/CD28}

Cells were cultured in OpTmizer ${ }^{\mathrm{TM}}$ CTS $^{\mathrm{TM}}$ T-Cell Expansion SFM. Cell viability was determined by the Trypan Blue exclusion test and exceeded $95 \%$. For in vitro cultures, cells were adjusted to $1 \times 10^{6}$ cells $/ \mathrm{mL}$. Human T lymphocytes, $\mathrm{CD} 4^{+}$and $\mathrm{CD} 8^{+}$lymphocytes 
$\left(5 \times 10^{5}\right.$ cells per culture) were activated with Dynabeads Human T-Activator CD3/CD28 ( $2.5 \mu \mathrm{L}$ beads per $10^{5}$ cells). All reagents were from Life Technologies Europe B.V., Zug, Switzerland. Cells were cultured for 5 days and analyzed by FACS. Culture supernatants were analyzed by multiplex ELISA as described previously [67]. Substances (vitamins, polyphenols) were added to cultures concomitantly to stimulation with immobilized anti$\mathrm{CD} 3 / \mathrm{CD} 28$.

\subsection{Cell Cytofluorometry}

Cells were resuspended in $\mathrm{HBSS} / 2 \% \mathrm{FCS} / 0.01 \% \mathrm{NaN}_{3}$ (HFN) and incubated with fluorochrome-conjugated antibodies for $45 \mathrm{~min}$ at $4{ }^{\circ} \mathrm{C}$. Subsequently, cells were washed $3 \times$ in HFN and resuspended in HFN containing 7-amino-actinomycin D (7-AAD) $(2.5 \mu \mathrm{g} / \mathrm{mL})$. Data of live (i.e., 7-AAD) cells were acquired with a FACS Calibur cytofluorometer (Becton Dickinson, Allschwil, Switzerland) and evaluated with Cellquest software (Becton Dickinson, Mountain View, CA, USA) as described [67].

\subsection{Measurement of Secreted Cytokines and Metabolites}

Secreted proteins and metabolites were quantified using multiplex ELISA kits obtained from Bio-Rad Laboratories (Hercules, CA, USA) and used in the LiquiChip Workstation IS 200 (Qiagen, Hilden, Germany) as described [39]. Data evaluation was done using the LiquiChip Analyser software (Qiagen, Hilden, Germany).

\subsection{Statistical Analysis}

Data are presented as mean $\pm \mathrm{SD}$ or \pm SEM. The difference between means was assessed by the student test and ANOVA using the SPSS software (IBM SPSS v22, Dynelytics AG, Zürich, Switzerland); $p$ values of $<0.05$ were considered to reflect statistically significant differences [39].

\subsection{Measurement of Gene Expression}

Total RNA was isolated from cells cultured for 4 days (Reference added in proof: T. Sekiya \& A. Yoshimura. In Vitro Th Differentiation Protocol. In: Xin-Hua Feng et al (eds.), TGF- $\beta$ Signaling Methods and Protocols Methods in Molecular Biology, vol 1344, DOI 10.10007/978-1-4939-2966-2, Springer Science-Business Media New York, 2016) and reverse-transcribed as detailed before [38,68]. Real-time PCR analysis was performed using the ABI 7900HT Fast Real-Time PCR System (ThermoFisher, Foster City, CA, USA). The $18 \mathrm{~S}$ rRNA primers and probes were internal standards. Relative gene expression was quantified by subtracting threshold cycles $\left(\mathrm{C}_{\mathrm{T}}\right)$ for ribosomal RNA from the $\mathrm{C}_{\mathrm{T}}$ of the targeted gene $\left(\Delta \mathrm{C}_{\mathrm{T}}\right)$. Relative mRNA levels were then calculated as $2^{\Delta \Delta \mathrm{CT}}$, where $\Delta \Delta^{\mathrm{CT}}$ refers to the $\Delta^{\mathrm{CT}}$ of unstimulated minus $\Delta^{\mathrm{CT}}$ treated cells [38]. Customized low density micro-arrays (LDA) were from Applied Biosystem ABI (Thermo Fisher Scientific, Waltham, MA, USA).

\section{Conclusions}

Vitamins, in particular vitamin D and bioactives like resveratrol and EGCG, alter the phenotype and function of T lymphocytes. Bioactives distinctly enforce or counterbalance the immune-regulatory effect of vitamin D. Since bioactives and vitamin D substantially differ in their physiological half-life, these substances might have distinct und mutually exclusive effects on the adaptive immune responses.

Supplementary Materials: The following are available online, Figure S1: Cells were negatively selected for CD3+, CD4+ and CD8+ lymphocytes. Figure S1a: Staining of CD3+-selected PBMCs with anti-CD4 and anti-CD8. Figure S1b: Staining of CD4+-selected PBMC with anti-CD4 and anti-CD8. Figure S1c: Staining of CD8+-selected PBMC with anti-CD4 and anti-CD8. Figure S2: Anti-CD3/CD28 activated cells were cultured for 5 days in the presence of the indicated substances and stained for CD4 and CD8 determinants. Table S1: Production of interleukins and cytokines by 
CD4+ and CD8+ subsets. Table S2: Prototypic Th1 and Th2 interleukins produced by anti-CD3/CD28 stimulated CD4+ lymphocytes in the presence of vitamins and vitamin metabolites.

Author Contributions: J.S., D.R., and I.B. conceived and designed the research. N.S., A.B., and J.S. performed the experimental work and compiled data. J.S. analyzed the data and wrote the manuscript. All authors have read and agreed to the published version of the manuscript.

Funding: Not applicable.

Institutional Review Board Statement: Not applicable.

Informed Consent Statement: Not applicable.

Data Availability Statement: The data presented in this study are available in Molecules.

Acknowledgments: We thank Silvia Manz for RT-PCR and Nathalie Richard for gene expression analysis using LDA.

Conflicts of Interest: The authors are employees of DSM Nutritional Products Ltd., which supported the study in the frame of a corporate program on nutrition and immunity.

Sample Availability: Samples of the compounds used in this study are commercially available.

\author{
Abbreviations \\ EGCG: epigallocatechin-3-gallate; IL, interleukin; PBMC, peripheral blood mononu- \\ clear cells; Res, resveratrol; VA, vitamin A; VD, 25(OH) vitamin $\mathrm{D}_{3}$; VE, vitamin $\mathrm{E}$ \\ (or $\alpha$-tocopherol).
}

\title{
References
}

1. Mosmann, T.R.; Kobie, J.J.; Lee, F.E.; Quataert, S.A. T helper cytokine patterns: Defined subsets, random expression, and external modulation. Immunol. Res. 2009, 45, 173-184. [CrossRef]

2. Zhu, J.; Paul, W.E. CD4 T cells: Fates, functions, and faults. Blood 2008, 112, 1557-1569. [CrossRef]

3. Kedzierski, L.; Curtis, J.M.; Doherty, P.C.; Handman, E.; Kedzierska, K. Decreased IL-10 and IL-13 production and increased CD44hi T cell recruitment contribute to Leishmania major immunity induced by non-persistent parasites. Eur. J. Immunol. 2008, 38, 3090-3100. [CrossRef]

4. Mora, J.R.; Iwata, M.; von Andrian, U.H. Vitamin effects on the immune system: Vitamins A and D take centre stage. Nat. Rev. Immunol. 2008, 8, 685-698. [CrossRef]

5. Von Essen, M.R.; Kongsbak, M.; Schjerling, P.; Olgaard, K.; Odum, N.; Geisler, C. Vitamin D controls T cell antigen receptor signaling and activation of human T cells. Nat. Immunol. 2010, 11, 344-349. [CrossRef]

6. Pichler, J.; Gerstmayr, M.; Szépfalusi, Z.; Urbanek, R.; Peterlik, M.; Willheim, M. 1 alpha,25(OH)2D3 inhibits not only Th1 but also Th2 differentiation in human cord blood T cells. Pediatr. Res. 2002, 52, 12-18. [CrossRef]

7. Canning, M.O.; Grotenhuis, K.; de Wit, H.; Ruwhof, C.; Drexhage, H.A. 1-alpha,25-Dihydroxyvitamin D3 (1,25(OH)(2)D(3)) hampers the maturation of fully active immature dendritic cells from monocytes. Eur. J. Endocrinol. 2001, 145, 351-357. [CrossRef]

8. Cantorna, M.T.; Nashold, F.E.; Hayes, C.E. In vitamin A deficiency multiple mechanisms establish a regulatory T helper cell imbalance with excess Th1 and insufficient Th2 function. J. Immunol. 1994, 152, 1515-1522.

9. Dawson, H.D.; Collins, G.; Pyle, R.; Key, M.; Weeraratna, A.; Deep-Dixit, V.; Nadal, C.N.; Taub, D.D. Direct and indirect effects of retinoic acid on human Th2 cytokine and chemokine expression by human T lymphocytes. BMC Immunol. 2006, 7, 27. [CrossRef]

10. Spilianakis, C.G.; Lee, G.R.; Flavell, R.A. Twisting the Th1/Th2 immune response via the retinoid X receptor: Lessons from a genetic approach. Eur. J. Immunol. 2005, 35, 3400-3404. [CrossRef]

11. Adolfsson, O.; Huber, B.T.; Meydani, S.N. Vitamin E-enhanced IL-2 production in old mice: Naive but not memory T cells show increased cell division cycling and IL-2-producing capacity. J. Immunol. 2001, 167, 3809-3817. [CrossRef]

12. Meydani, S.N.; Han, S.N.; Wu, D. Vitamin E and immune response in the aged: Molecular mechanisms and clinical implications. Immunol. Rev. 2005, 205, 269-284. [CrossRef] [PubMed]

13. Meydani, S.N.; Meydani, M.; Verdon, C.P.; Shapiro, A.A.; Blumberg, J.B.; Hayes, K.C. Vitamin E supplementation suppresses prostaglandin E1(2) synthesis and enhances the immune response of aged mice. Mech. Ageing Dev. 1986, 34, 191-201. [CrossRef]

14. Kuo, C.L.; Chen, T.S.; Liou, S.Y.; Hsieh, C.C. Immunomodulatory effects of EGCG fraction of green tea extract in innate and adaptive immunity via T regulatory cells in murine model. Immunopharmacol. Immunotoxicol. 2014, 36, 364-370. [CrossRef] [PubMed]

15. Pae, M.; Ren, Z.; Meydani, M.; Shang, F.; Smith, D.; Meydani, S.N.; Wu, D. Dietary supplementation with high dose of epigallocatechin-3-gallate promotes inflammatory response in mice. J. Nutr. Biochem. 2012, 23, 526-531. [CrossRef] [PubMed]

16. Wong, C.P.; Nguyen, L.P.; Noh, S.K.; Bray, T.M.; Bruno, R.S.; Ho, E. Induction of regulatory T cells by green tea polyphenol EGCG. Immunol. Lett. 2011, 139, 7-13. [CrossRef] 
17. Wu, D. Green tea EGCG, T-cell function, and T-cell-mediated autoimmune encephalomyelitis. J. Investig. Med. 2016, 64, 1213-1219. [CrossRef]

18. Wu, D.; Guo, Z.; Ren, Z.; Guo, W.; Meydani, S.N. Green tea EGCG suppresses T cell proliferation through impairment of IL-2/IL-2 receptor signaling. Free Radic. Biol. Med. 2009, 47, 636-643. [CrossRef]

19. Craveiro, M.; Cretenet, G.; Mongellaz, C.; Matias, M.I.; Caron, O.; de Lima, M.C.P.; Zimmermann, V.S.; Solary, E.; Dardalhon, V.; Dulic, V.; et al. Resveratrol stimulates the metabolic reprogramming of human CD4(+) T cells to enhance effector function. Sci. Signal. 2017, 10, 1-14. [CrossRef]

20. Falchetti, R.; Fuggetta, M.P.; Lanzilli, G.; Tricarico, M.; Ravagnan, G. Effects of resveratrol on human immune cell function. Life Sci. 2001, 70, 81-96. [CrossRef]

21. Ford, C.T.; Richardson, S.; McArdle, F.; Lotito, S.B.; Crozier, A.; McArdle, A.; Jackson, M.J. Identification of (poly)phenol treatments that modulate the release of pro-inflammatory cytokines by human lymphocytes. Br. J. Nutr. 2016, 115, 1699-1710. [CrossRef] [PubMed]

22. Gao, X.; Deeb, D.; Media, J.; Divine, G.; Jiang, H.; Chapman, R.A.; Gautam, S.C. Immunomodulatory activity of resveratrol: Discrepant in vitro and in vivo immunological effects. Biochem. Pharmacol. 2003, 66, 2427-2435. [CrossRef]

23. Gao, X.; Xu, Y.X.; Janakiraman, N.; Chapman, R.A.; Gautam, S.C. Immunomodulatory activity of resveratrol: Suppression of lymphocyte proliferation, development of cell-mediated cytotoxicity, and cytokine production. Biochem. Pharmacol. 2001, 62, 1299-1308. [CrossRef]

24. Lai, X.; Pei, Q.; Song, X.; Zhou, X.; Yin, Z.; Jia, R.; Zou, Y.; Li, L.; Yue, G.; Liang, X.; et al. The enhancement of immune function and activation of NF-kappaB by resveratrol-treatment in immunosuppressive mice. Int. Immunopharmacol. 2016, 33, 42-47. [CrossRef]

25. Rachon, D.; Rimoldi, G.; Wuttke, W. In vitro effects of genistein and resveratrol on the production of interferon-gamma (IFNgamma) and interleukin-10 (IL-10) by stimulated murine splenocytes. Phytomedicine 2006, 13, 419-424. [CrossRef]

26. Sharma, S.; Chopra, K.; Kulkarni, S.K.; Agrewala, J.N. Resveratrol and curcumin suppress immune response through CD28/CTLA4 and CD80 co-stimulatory pathway. Clin. Exp. Immunol. 2007, 147, 155-163. [CrossRef]

27. Yang, Y.; Paik, J.H.; Cho, D.; Cho, J.A.; Kim, C.W. Resveratrol induces the suppression of tumor-derived CD $4^{+} \mathrm{CD} 25^{+}$regulatory $\mathrm{T}$ cells. Int. Immunopharmacol. 2008, 8, 542-547. [CrossRef] [PubMed]

28. Gajewski, T.F.; Schell, S.R.; Nau, G.; Fitch, F.W. Regulation of T-cell activation: Differences among T-cell subsets. Immunol. Rev. 1989, 111, 79-110. [CrossRef] [PubMed]

29. Diehl, S.; Rincon, M. The two faces of IL-6 on Th1/Th2 differentiation. Mol. Immunol. 2002, 39, 531-536. [CrossRef]

30. Feng, Y.H.; Zhu, Y.N.; Liu, J.; Ren, Y.X.; Xu, J.Y.; Yang, Y.F.; Li, X.Y.; Zou, J.P. Differential regulation of resveratrol on lipopolysacchride-stimulated human macrophages with or without IFN-gamma pre-priming. Int. Immunopharmacol. 2004, 4, 713-720. [CrossRef]

31. Shim, J.H.; Choi, H.S.; Pugliese, A.; Lee, S.Y.; Chae, J.I.; Choi, B.Y.; Bode, A.M.; Dong, Z. (-)-Epigallocatechin gallate regulates CD3-mediated T cell receptor signaling in leukemia through the inhibition of ZAP-70 kinase. J. Biol. Chem. 2008, 283, 28370-28379. [CrossRef] [PubMed]

32. Kim, C.H.; Broxmeyer, H.E. Chemokines: Signal lamps for trafficking of T and B cells for development and effector function. J. Leukoc. Biol. 1999, 65, 6-15. [CrossRef] [PubMed]

33. Frazzi, R.; Guardi, M. Cellular and Molecular Targets of Resveratrol on Lymphoma and Leukemia Cells. Molecules 2017, $22,885$. [CrossRef]

34. Kelsey, N.A.; Wilkins, H.M.; Linseman, D.A. Nutraceutical antioxidants as novel neuroprotective agents. Molecules 2010, 15, 7792-7814. [CrossRef] [PubMed]

35. Das, S.K.; Mukherjee, S.; Gupta, G.; Rao, D.N.; Vasudevan, D.M. Protective effect of resveratrol and vitamin E against ethanolinduced oxidative damage in mice: Biochemical and immunological basis. Indian J. Biochem. Biophys. 2010, 47, 32-37. [PubMed]

36. Salinthone, S.; Kerns, A.R.; Tsang, V.; Carr, D.W. alpha-Tocopherol (vitamin E) stimulates cyclic AMP production in human peripheral mononuclear cells and alters immune function. Mol. Immunol. 2013, 53, 173-178. [CrossRef]

37. Porath, D.; Riegger, C.; Drewe, J.; Schwager, J. Epigallocatechin-3-gallate impairs chemokine production in human colon epithelial cell lines. J. Pharmacol. Exp. Ther. 2005, 315, 1172-1180. [CrossRef]

38. Richard, N.; Porath, D.; Radspieler, A.; Schwager, J. Effects of resveratrol, piceatannol, tri-acetoxystilbene, and genistein on the inflammatory response of human peripheral blood leukocytes. Mol. Nutr. Food Res. 2005, 49, 431-442. [CrossRef] [PubMed]

39. Schwager, J.; Richard, N.; Widmer, F.; Raederstorff, D. Resveratrol distinctively modulates the inflammatory profiles of immune and endothelial cells. BMC Complement. Altern. Med. 2017, 17, 309. [CrossRef]

40. Zou, T.; Yang, Y.; Xia, F.; Huang, A.; Gao, X.; Fang, D.; Xiong, S.; Zhang, J. Resveratrol Inhibits CD4 ${ }^{+}$T cell activation by enhancing the expression and activity of Sirt1. PLoS ONE 2013, 8, e75139. [CrossRef]

41. Espinoza, J.L.; Trung, L.Q.; Inaoka, P.T.; Yamada, K.; An, D.T.; Mizuno, S.; Nakao, S.; Takami, A. The Repeated Administration of Resveratrol Has Measurable Effects on Circulating T-Cell Subsets in Humans. Oxid. Med. Cell Longev. 2017, $2017,6781872$. [CrossRef]

42. Schwager, J.; Richard, N.; Riegger, C.; Salem, N., Jr. omega-3 PUFAs and Resveratrol Differently Modulate Acute and Chronic Inflammatory Processes. Biomed. Res. Int. 2015, 2015, 535189. [CrossRef]

43. Delmas, D.; Limagne, E.; Ghiringhelli, F.; Aires, V. Immune Th17 lymphocytes play a critical role in the multiple beneficial properties of resveratrol. Food Chem. Toxicol. 2020, 137, 111091. [CrossRef] 
44. Shimizu, M.; Weinstein, I.B. Modulation of signal transduction by tea catechins and related phytochemicals. Mutat. Res. 2005, 591, 147-160. [CrossRef]

45. Ide, K.; Kawasaki, Y.; Kawakami, K.; Yamada, H. Anti-influenza Virus Effects of Catechins: A Molecular and Clinical Review. Curr. Med. Chem. 2016, 23, 4773-4783. [CrossRef]

46. Ruiter, B.; Patil, S.U.; Shreffler, W.G. Vitamins A and D have antagonistic effects on expression of effector cytokines and gut-homing integrin in human innate lymphoid cells. Clin. Exp. Allergy 2015, 45, 1214-1225. [CrossRef] [PubMed]

47. Stephensen, C.B.; Jiang, X.; Freytag, T. Vitamin A deficiency increases the in vivo development of IL-10-positive Th2 cells and decreases development of Th1 cells in mice. J. Nutr. 2004, 134, 2660-2666. [CrossRef] [PubMed]

48. Askari, A.; Naghizadeh, M.M.; Homayounfar, R.; Shahi, A.; Afsarian, M.H.; Paknahad, A.; Kennedy, D.; Ataollahi, M.R. Increased Serum Levels of IL-17A and IL-23 Are Associated with Decreased Vitamin D3 and Increased Pain in Osteoarthritis. PLoS ONE 2016, 11, e0164757. [CrossRef]

49. Edfeldt, K.; Liu, P.T.; Chun, R.; Fabri, M.; Schenk, M.; Wheelwright, M.; Keegan, C.; Krutzik, S.R.; Adams, J.S.; Hewison, M.; et al. T-cell cytokines differentially control human monocyte antimicrobial responses by regulating vitamin D metabolism. Proc. Natl. Acad. Sci. USA 2010, 107, 22593-22598. [CrossRef] [PubMed]

50. Goncalves-Mendes, N.; Talvas, J.; Dualé, C.; Guttmann, A.; Corbin, V.; Marceau, G.; Sapin, V.; Brachet, P.; Evrard, B.; Laurichesse, H.; et al. Impact of Vitamin D Supplementation on Influenza Vaccine Response and Immune Functions in Deficient Elderly Persons: A Randomized Placebo-Controlled Trial. Front. Immunol. 2019, 10, 65. [CrossRef]

51. Imazeki, I.; Matsuzaki, J.; Tsuji, K.; Nishimura, T. Immunomodulating effect of vitamin D3 derivatives on type-1 cellular immunity. Biomed. Res. 2006, 27, 1-9. [CrossRef] [PubMed]

52. Kongsbak, M.; von Essen, M.R.; Levring, T.B.; Schjerling, P.; Woetmann, A.; Odum, N.; Bonefeld, C.M.; Geisler, C. Vitamin D-binding protein controls T cell responses to vitamin D. BMC Immunol. 2014, 15, 35. [CrossRef]

53. Mahon, B.D.; Wittke, A.; Weaver, V.; Cantorna, M.T. The targets of vitamin D depend on the differentiation and activation status of CD4 positive T cells. J. Cell Biochem. 2003, 89, 922-932. [CrossRef] [PubMed]

54. Rahman, S.; Rehn, A.; Rahman, J.; Andersson, J.; Svensson, M.; Brighenti, S. Pulmonary tuberculosis patients with a vitamin D deficiency demonstrate low local expression of the antimicrobial peptide LL-37 but enhanced FoxP3 ${ }^{+}$regulatory T cells and IgG-secreting cells. Clin. Immunol. 2015, 156, 85-97. [CrossRef]

55. Sheikh, V.; Kasapoglu, P.; Zamani, A.; Basiri, Z.; Tahamoli-Roudsari, A.; Alahgholi-Hajibehzad, M. Vitamin D3 inhibits the proliferation of T helper cells, downregulate CD4(+) T cell cytokines and upregulate inhibitory markers. Hum. Immunol. 2018, 79, 439-445. [CrossRef]

56. Wittke, A.; Weaver, V.; Mahon, B.D.; August, A.; Cantorna, M.T. Vitamin D receptor-deficient mice fail to develop experimental allergic asthma. J. Immunol. 2004, 173, 3432-3436. [CrossRef]

57. Dampf Stone, A.; Batie, S.F.; Sabir, M.S.; Jacobs, E.T.; Lee, J.H.; Whitfield, G.K.; Haussler, M.R.; Jurutka, P.W. Resveratrol potentiates vitamin D and nuclear receptor signaling. J. Cell Biochem. 2015, 116, 1130-1143. [CrossRef] [PubMed]

58. Guo, C.; Sinnott, B.; Niu, B.; Lowry, M.B.; Fantacone, M.L.; Gombart, A.F. Synergistic induction of human cathelicidin antimicrobial peptide gene expression by vitamin D and stilbenoids. Mol. Nutr. Food Res. 2014, 58, 528-536. [CrossRef]

59. Amin, A.; Wang, D.; Nannapaneni, S.; Lamichhane, R.; Chen, Z.G.; Shin, D.M. Combination of resveratrol and green tea epigallocatechin gallate induces synergistic apoptosis and inhibits tumor growth in vivo in head and neck cancer models. Oncol. Rep. 2021, 45, 87. [CrossRef]

60. Asou, H.; Koshizuka, K.; Kyo, T.; Takata, N.; Kamada, N.; Koeffier, H.P. Resveratrol, a natural product derived from grapes, is a new inducer of differentiation in human myeloid leukemias. Int. J. Hematol. 2002, 75, 528-533. [CrossRef]

61. Cheng, J.; Xia, X.; Rui, Y.; Zhang, Z.; Qin, L.; Han, S.; Wan, Z. The combination of 1alpha,25dihydroxyvitaminD3 with resveratrol improves neuronal degeneration by regulating endoplasmic reticulum stress, insulin signaling and inhibiting tau hyperphosphorylation in SH-SY5Y cells. Food Chem. Toxicol. 2016, 93, 32-40. [CrossRef] [PubMed]

62. Faggi, L.; Porrini, V.; Lanzillotta, A.; Benarese, M.; Mota, M.; Tsoukalas, D.; Parrella, E.; Pizzi, M. A Polyphenol-Enriched Supplement Exerts Potent Epigenetic-Protective Activity in a Cell-Based Model of Brain Ischemia. Nutrients 2019, 11, 345. [CrossRef] [PubMed]

63. Lee, M.J.; Maliakal, P.; Chen, L.; Meng, X.; Bondoc, F.Y.; Prabhu, S.; Lambert, G.; Mohr, S.; Yang, C.S. Pharmacokinetics of tea catechins after ingestion of green tea and (-)-epigallocatechin-3-gallate by humans: Formation of different metabolites and individual variability. Cancer Epidemiol. Biomark. Prev. 2002, 11, 1025-1032.

64. Ullmann, U.; Haller, J.; Decourt, J.D.; Girault, J.; Spitzer, V.; Weber, P. Plasma-kinetic characteristics of purified and isolated green tea catechin epigallocatechin gallate (EGCG) after 10 days repeated dosing in healthy volunteers. Int. J. Vitam. Nutr. Res. 2004, 74, 269-278. [CrossRef]

65. Walle, T.; Hsieh, F.; DeLegge, M.H.; Oatis, J.E., Jr.; Walle, U.K. High absorption but very low bioavailability of oral resveratrol in humans. Drug Metab. Dispos. 2004, 32, 1377-1382. [CrossRef] [PubMed]

66. Jetter, A.; Egli, A.; Dawson-Hughes, B.; Staehelin, H.B.; Stoecklin, E.; Goessl, R.; Henschkowski, J.; Bischoff-Ferrari, H.A. Pharmacokinetics of oral vitamin D(3) and calcifediol. Bone 2014, 59, 14-19. [CrossRef] 
67. Schwager, J.; Bompard, A.; Weber, P.; Raederstorff, D. Ascorbic acid modulates cell migration in differentiated HL-60 cells and peripheral blood leukocytes. Mol. Nutr. Food Res. 2015, 59, 1513-1523. [CrossRef]

68. Schwager, J.; Gagno, L.; Richard, N.; Simon, W.; Weber, P.; Bendik, I. Z-ligustilide and anti-inflammatory prostaglandins have common biological properties in macrophages and leukocytes. Nutr. Metab. 2018, 15, 4. [CrossRef] 